\title{
PROBLEMATIKA KINERJA PENDIDIK DI LINGKUNGAN PENDIDIKAN ISLAM
}

\author{
MUHAMMAD ABDUL GANI
}

\begin{abstract}
This article highlights the problems faced by educators in the Islamic education environment. Islamic identity in Islamic educational institutions is not a reason for educators to live and carry out their duties properly and professionally. The lack of awareness of this causes educators to pay less attention to the quality of the educational process provided. The difference in ministerial nomenclature that houses educational institutions also indirectly influences many matters relating to the activities of teachers as professional educators. In addition, other issues that have become the problem of educators in the Islamic education environment occur due to internal and external factors of educators, including official operational problems and institutions, educators' competencies and qualifications, welfare and leadership crisis in Islamic education institutions. This research uses literature review method by searching various sources of literature that are relevant to the research subject.
\end{abstract}

Keywords: Educator performance, Islamic education environment

\section{Pendahuluan}

Setiap manusia dilahirkan ke dunia ini dengan keadaan lemah dan tidak memiliki pengetahuan apa-apa. Namun Allah swt membekali manusia dengan berbagai potensi dasar berupa penglihatan, pendengaran dan juga akal fikiran (Q.S.An-Nahl, 16:78). Tugas manusia selanjutnya adalah memelihara dan mengembangkan potensi tersebut agar menjadi hamba yang beryukur. Namun dalam menjalaninya, manusia membutuhkan bimbingan melalui sebuah proses yang dinamakan pendidikan.

Sebuah proses pendidikan memiliki unsur yang saling berkaitan dan tidak bisa dipisahkan satu dengan yang lainnya. Guru yang merupakan salah satu stakeholder pendidikan menjadi ujung tombak dalam keberhasilan proses pendidikan tersebut. Guru sejati tidak hanya menjadi fasilitator dalam proses transfer of knowladge saja, melainkan guru sebagai pendidik yang memusatkan proses pendidikan pada optimalisasi potensi setiap individu sebagai peserta didik.

Dalam perspektif tradisional, guru merupakan akronim dari kata digugu dan ditiru. Digugu artinya kata-kata guru senantiasa didengar, dipercaya, diyakini dan dilaksanakan sebagai suatu kebenaran dan kehormatan oleh murid. Ditiru artinya 
seorang guru harus memiliki akhlakul karimah sehingga perilaku dan tutur katanya menjadi teladan dan akhirnya ditiru oleh peserta didik.

Sudah menjadi kewajiban seorang guru yang profesional sebagai pendidik yang ideal untuk memenuhi persyaratan kualifikasi pendidikan dan kompetensi keilmuan, diantaranya dengan memiliki kemampuan public speaking yang baik yang akan berpengaruh pada cara ia berkomunikasi dengan peserta didik dan atau wali murid. Guru juga dituntut untuk berjiwa kreatif, inovatif dan produktif. Komitmen serta etos kerja yang tinggi akan profesinya dan memiliki ketamakan ilmu pengetahuan dengan melakukan pengembangan diri secara berkesinambungan.

Pendidik memainkan peran yang berdampak pada kualitas pendidikan yang dijalankan. Dalam sejarahnya, pendidik atau guru di Indonesia tidak terlepas dari kebijakan dan perubahan sistem yang diterapkan dari masa ke masa. Pemerintah senantiasa mengembangkan pemikiran tentang solusi dari permasalahan yang dihadapi oleh sistem pendidikan di Indonesia dengan mengeluarkan berbagai inovasi pada kurikulum nasional yang diharapkan bisa memberikan solusi dan memperbaiki sistem yang ada. Dengan tujuan agar sistem pendidikan di Indonesia mampu bersaing di era globalisasi ini. Namun dalam proses perjalanannya, terdapat banyak permasalahan-permasalahan. Salah satunya adalah masalah kinerja dari pendidik yang berperan sebagai eksekutor di lapangan.

Pada dasarnya, kinerja merupakan sebuah pencapaian kerja yang diraih oleh seorang guru dalam melaksanakan tugas dan fungsinya sebagai pendidik secara profesional. Baiknya kualitas kinerja guru akan menentukan tingkat keberhasilan proses pendidikan, karena guru adalah sosok yang bersentuhan secara langsung dengan para siswa dalam proses pendidikan atau pembelajaran di lembaga pendidikan. Maka seyogyanya seorang guru dituntut untuk memiliki kinerja yang optimal dalam rangka mewujudkan sekolah yang berkualitas dan berintegritas.

Sistem pendidikan di Indonesia telah mengalami reformasi berkali-kali sejak masa kemerdekaan hingga saat ini. Dilihat dari jenis pendidikannya, secara umum pendidikan di Indonesia dibedakan menjadi dua, yaitu pendidikan umum dan pendidikan Agama. Kemeterian yang menaungi kedua jenis pendidikan inipun berbeda. Kementerian Pendidikan dan Kebudayaan (Kemendikbud) dan Kementerian Pendidikan Tinggi Riset dan Teknologi (Kemenristek Dikti) menaungi lembaga pendidikan umum. Sedangkan Kementerian Agama menaungi pendidikan agama dari mulai pesantren, madrasah diniah sampai perguruan tinggi islam. Hal tersebut secara tidak langsung memberikan pengaruh terhadap kualifikasi dan kompetensi pendidik yang dihasilkan. Karena masing-masing kementerian memiliki tehnik dan pendekatan yang berbeda dalam menghasilkan output yang diinginkan.

Selain kualifikasi pendidik, perbedaan nomenklatur di atas juga membentuk lingkungan pendidikan yang berbeda. Lembaga-lembaga yang bernaung dibawah kementerian Agama cenderung lebih bersifat agamis dibanding lembaga yang bernaung di bawah kementerian pendidikan dan kebudayaan, namun di sisi lain juga memiliki disiplin yang lebih baik. Intinya keduanya memiliki sifat dan karakteristik yang berbeda dengan kelebihan dan kekurangan masing-masing, termasuk pada problematika yang dihadapi oleh para pendidiknya. Walaupun sebenarnya pada 
banyak kasus muncul kesamaan antara masalah kinerja pendidik yang dihadapi di lingkungan pendidikan umum dan yang dihadapi di lingkungan pendidikan islam.

Lembaga pendidikan yang berada di lingkungan pendidikan islam yang syarat akan nilai-nilai keislaman ternyata tidak menjamin seseorang akan menjalankan tugas dan fungsinya dengan baik. Hal itu kembali kepada pribadi yang menjalankan. Tentunya dipengaruhi juga oleh faktor-faktor yang menyebabkan baik atau buruknya kinerja.

Masalah ini menarik dan menjadi isu mendasar dalam dunia pendidikan islam. Identitas keislaman tidak selalu menjadikan seorang pendidik menghayati bahwa pekerjaannya adalah sebuah tugas yang mulia, yang apabila dikerjakan dengan suka cita dan penuh keikhlasan akan mendapatkan balasan surga. Kurangnya kesadaran akan hal tersebut dan dorongan kebutuhan duniawi, serta faktor lainnnya menyebabkan para pendidik tidak menghiraukan kualitas dari pendidikan yang diberikan. Sekedar lepas dari tanggung jawab profesi saja.

Upaya-upaya telah banyak dilakukan untuk meningkatkan kinerja pendidik melalui internalisasi nilai, pelatihan guru, seminar termasuk melalui kebijakankebijakan yang dikeluarkan oleh pemerintan. Hal tersebut menjadi solusi bagi banyak masalah yang dihadapi namun kecil pengaruhnya bagi masalah lain dan bahkan menimbulkan masalah baru. Salah satu contoh kasus adalah dengan adanya hasil penelitian yang membahas tentang efektifitas sertifikasi atau tunjangan profesi guru (TPG) terhadap peningkatan kinerja seorang pendidik. Sertifikasi tersebut ada yang mendorong penerimanya untuk meningkatkan kinerjanya tapi ada pula yang tidak memberikan dampak apa-apa. Hal inilah yang berusaha penulis gali, yaitu tentang problematika yang dihadapi oleh para guru dalam menjalankan tugas dan fungsinya sebagai pendidik yang profesional.

Agar pembahasannya tidak meluas, penulis membatasi penulisan artikel ini pada problematika yang dihadapi oleh para pendidik khusunya yang bertugas di lingkungan pendidikan islam. Maka permasalahan tulisan ini dapat dirumuskan dalam bentuk pertanyaan "Bagaimana problematika kinerja pendidik di lingkungan pendidikan islam?"

Penelitian ini menggunakan metode kajian konseptual atau survei of literature atau disebut juga literature review. Metode penelitian ini bukan hanya membaca dan mengutip literatur saja, melainkan penulis harus mengevaluasi secara mendalam dan kritis terhadap penelitian yang sudah dilakukan sebelumnya yang sesuai dengan topik pembahasan penulis.

Menurut Hasibuan (2007:42), Literatur review merupakan uraian tentang teoriteori yang ditemukan dalam berbagai sumber primer dan sekunder sebagai bahan acuan yang kemudian dijadikan bahan penelitian baru oleh peneliti sebagai landasan kegiatan penelitian. Uraian dalam literatur review ini bertujuan untuk menyusun kembali kerangka pemikiran peneliti tentang pemecahan permasalahan yang telah dipaparkan sebelumnya pada perumusan masalah.

Penelitian ini diawali dengan menelusuri berbagai literatur yang berhubungan dengan subyek penelitian. Penelusuran ini adalah langkah pertama untuk mengumpulkan data dan informasi yang relevan bagi peneliti. Penelusuran literatur 
yang relevan juga berguna untuk menghindarkan praktik duplikasi dari pelaksanaan penelitian. Karena pencarian penelitian yang pernah dilakukan yang relevan dengan penelitian yang penulis kerjakan bisa diketahui melalui kajian pustaka.

Langkah-langkah yang diambil dalam penelitian ini adalah formulasi permasalahan, pencarian literatur, evaluasi data dan menganalisis serta menginterpretasikan data yang sudah di peroleh (Hasibuan, 2007:42).

\section{Metode Kajian}

Metode penelitian yang digunakan dalam penelitian ini adalah metode deskriptif-analisis dengan pendekatan kualitatif. Adapun teknik pengumpulan data yang digunakan adalah studi literatur, yang dilakukan dengan cara mengumpulkan data dari artikel-artikel ilmiah dan buku-buku yang relevan dengan masalah penelitian.

\section{Hasil Kajian dan Pembahasan}

Orang dewasa bertanggung jawab terhadap seorang anak dalam memberikan bantuan untuk mengembangkan jasmani dan ruhaninya agar anak tersebut tumbuh dewasa dengan jiwa kemandirian sehingga mampu memenuhi kebutuhannya seharihari serta menjalankan tugasnya sebagai hamba dan khalifat Allah SWT di muka bumi ini. Selain itu, bimbingan dari orang dewasa juga bertujuan agar anak tersebut mampu melaksanakan fungsinya sebagai makhluk sosial yang melakukan interaksi dan sosialisasi dengan masyarakat dan sebagai makhluk individu yang berdikari dan tangguh (Umar, 2010: 83).

Ahmad Tafsir (2008:74) berpendapat bahwa pendidik dalam konteks pendidikan Islam merupakan bagian terpenting. Pendidik dalam Islam adalah orangorang yang bertanggung jawab terhadap perkembangan peserta didiknya dengan upaya mengembangkan seluruh potensi peserta didik, baik potensi afektif (rasa), kognitif (cipta), maupun psikomotorik (karsa).

Orang dengan tanggung jawab yang paling besar terhadap pengembangan dan pertumbuhan potensi anak adalah kedua orang tua (ayah dan ibu) dari anak tersebut. Tanggung jawab itu disebabkan karena dua hal. Pertama, karena kodrat yaitu karena orang tua telah ditakdirkan menjadi ayah dan ibu anaknya, dan karena itu ia juga ditakdirkan memiliki tanggung jawab untuk mendidik anaknya. Kedua, karena adanya kepentingan kedua orang tua, yaitu orang tua berkepentingan untuk menjamin kemajuan pertumbuhan dan perkembangan anaknya. Selain itu sukses tidaknya anak mereka dalam menjalani kehidupan juga sangat tergantung pada pola pengasuhan, bimbingan dan pendidikan yang diberikan oleh kedua orang tua di lingkungan rumah (Tafsir, 2008:74). Keterangan tersebut tergambar dalam Quran Surat Al-Tahrim ayat 6 yang artinya "Wahai orang-orang beriman, peliharalah dirimu dan keluargamu dari api neraka” (Q.S. At-Tahrim, 66:6).

Menurut Ibnu Abbas radhiyallahu 'anhuma, makna ayat tersebut adalah kita harus meningkatkan ketaatan kita kepada Allah dan meninggalkan maksiat serta mengajak keluarga kita untuk senantiasa taat kepada Allah swt dengan terus 
berdzikir kepadaNya. Maka dengannya Allah akan menyelamatkan kita dan keluarga kita dari panasnya api neraka. Sementara Ali bin Abi Thalib radhiyallahu 'anhu mengatakan bahwa maknanya potongan ayat di atas adalah "addibhum wa 'allimhum" yang artinya didiklah mereka dan ajarkan ilmu kepada mereka. Ali bin Abi Thalib melakukan pendekatan edukatif dalam menjelaskan ayat di atas. Bahwa cara merealisasikan ketaatan kita kepada Allah swt adalah dengan mengajarkan dan mendidik anggota keluarga kita dengan ajaran-ajaran agama. Sehingga dengan ilmu, amalan yang dilakukan akan diterima oleh Allah swt dan kita serta keluarga kita bisa terlindung dari api neraka. Sedangkan Muqatil dan Ad Dhahak berkata, makna peliharalah dirimu dan keluargamu dari api neraka adalah seorang kepala keluarga harus memerintahkan anggota keluarganya untuk mencintai dan mentaati Allah swt dan mencegah mereka dari berlaku maksiat kepada Allah swt. Seorang kepala keluarga juga hendaknya menegakkan perintah Allah yang berhubungan dengan anggota keluarga, seperti memerintahkan istri untuk menutup aurat. Jika ada anggota keluarga yang melanggar perintah Allah maka kepala keluarga berkewajiban untuk menegur dan mengingatkannya agar kembali kepada jalan Allah swt. (Tafsir Ibnu Katsir:4/391).

Menurut Ramayulis (2002:58), ada 5 sosok pendidik dalam pendidikan islam. Pertama, Allah swt yang Maha Mengetahui dan Maha Bijaksana, sumber dari segala pengetahuan. Kedua, Nabi Muhammad saw sebagai utusan Allah yang ditugaskan untuk menyampaikan ajaran-ajaran yang telah diwahyukan dan menjadi suri tauladan bagi segenap ummat manusia. Ialah sebaik-baiknya pendidik yang telah berhasil mendidik bangsa arab dan membawa mereka dari jaman jahiliah kedalam jaman ketauhidan. Ketiga, Ulama sebagai pewaris para nabi yang melanjutkan estafeta perjuangan para nabi dalam menyebarkan ilmu pengetahuan dan syariat keagamaan. Keempat, orang tua sebagai pendidik di lingkungan keluarga. Seorang ibu yang merupakan sekolah pertama bagi anaknya. Dan ayah yang mengajarkan makna kehidupan. Kelima, guru sebagai pendidik di lingkungan lembaga pendidikan baik formal maupun non formal yang menjalankan tugasnya secara profesional berdasarkan kualifikasinya.

Dari kelima pendidik yang dipaparkan oleh Ramayulis di atas, 3 diantaranya mendidik kita secara langsung bertatap muka dan bersentuhan langsung dengan peserta didik, yaitu ulama, orang tua dan guru. Sedangkan Allah swt mendidik kita melalui firman-Nya dan tanda-tanda kekuasaan-Nya. Nabi Muhammad saw mendidik kita melalui keteladanan yang telah dicontohkan melalui riwayat-riwayat hadis berupa ilmu pengetahuan, kisah penuh hikmah dan sunnah-sunnah yang diamalkannya.

Dalam kontek pendidikan secara umum guru memiliki makna yang luas mencakup seluruh kegiatan mendidik dan mengajarkan ilmu dimanapun siapapun dan kapanpun. Namun dalam konteks jabatan, makna guru memiliki batasan yaitu mereka yang profesinya mendidik pada lembaga pendidikan formal, dari pendidikan Dasar sampai menengah. Sementara mereka yang mengajar di lembanga pendidikan tinggi disebut dosen (kosim, 2012:11). Menurut PP No. 74 Tahun 2008, guru adalah pendidik profesional dengan tugas dan fungsi mendidik, membimbing, mengarahkan, mengajar, melatih, menilai dan melakukan evaluasi atas semua proses yang dijalani peserta didik pada tingkat pendidikan anak usia dini (PAUD) jalur pendidikan formal, 
pendidikan dasar dan pendidikan menengah (Pasal 1 Ayat 1 PP No.74 : 2008). Undang-Undang Nomer 14 Tahun 2005 menjelaskan definisi dosen yang merupakan tenaga pendidik profesional dan seorang ilmuan dengan tugas utama untuk mentransformasikan, mengembangkan serta menyebarluaskan ilmu pengetahuan, teknologi dan seni kepada para mahasiswa di tingkat strata satu, dua atau tiga melalui tri dharma perguruan tinggi yaitu pendidikan, penelitian dan pengabdian kepada masyarakat (Pasal 1 Ayat 2 UU No.14 :2015).

Undang-Undang Guru dan Dosen No. 14 Tahun 2005 juga menjelaskan bahwa guru harus memiliki kualifikasi dan kompetensi akademik. Kualifikasi yang harus dimiliki guru profesional berupa pendidikan minimal sarjana atau progam diploma empat. Sedangkan kompetensi yang harus dimiliki oleh guru profesional meliputi kompetensi pedagogik, kompetensi kepribadian, kompetensi sosial dan kompetensi profesional yang diperoleh melalui pendidikan profesi.

Kompetensi tersebut bersifat holistik. Peraturan pemerintah nomor 74 tahun 2008 membahas secara mendetail mengenai kompetensi yang harus dimiliki oleh seorang guru. Pertama, kompetensi pedagogik yang merupakan kemampuan guru dalam mengelola pembelajaran di kelas. Kompetensi pedagogik ini meliputi kemampuan guru dalam memahami peserta didik, mengembangkan administrasi pembelajaran berupa silabus, rencana pelaksanaan pembelajaran (RPP), evaluasi hasil belajar juga mengembangkan setiap potensi yang dimiliki oleh peserta didik. Kedua, kompetensi kepribadian. Seorang guru harus memiliki kepribadin yang baik yang mencakup keimanan dan ketakwaan, berakhlak mulia, demokratis, arif dan bijaksana dalam menentukan keputusan, berwibawa, emosi stabil dan tidak tempramen, bersikap dewasa, jujur dan sportif, bersikap objektif, menjadi teladan dan memiliki keinginan untuk mengembangkan diri secara mandiri dan berkelanjutan, sehingga menjadikan keilmuan yang dimiliki terus berkembang. Ketiga, kompetensi sosial. Seorang guru adalah juga manusia yang merupakan mahluk sosial. Maka kemampuannya dalam berinteraksi dengan mahluk lain juga menjadi kompetensi yang harus dimiliki guru. Diantar sikap dalam kompetensi soial ini adalah senantiasa bersikap santun dalam berkomunikasi, tidak berlebihan dalam menggunakan teknologi komunikasi dan media sosial, mampu bergaul secara efektif dengan semua pihak dan golongan baik antar sesama pendidik, peserta didik, wali peserta didik dan atau masyarakat umum, bergaul secara baik dengan lingkungan dan menerapkan prinsip persaudaraan dalam kebersamaan (ukhuwah basyariah). Keempat, guru harus menguasai kompetensi profesional yang meliputi penguasaan materi atau bahan ajar yang akan disampaikan kepada siswa melalui model, strategi dan metode pembelajaran yang kreatif dan inovatif.

\section{Konsep Kinerja}

Secara etimologi, kinerja merupakan terjemahan dari kata performance (bahasa Inggris) yang berarti pekerjaan atau perbuatan. Kata performance memiliki tiga arti yaitu: Pertama, prestasi. Kedua, pertunjukan dan yang ketiga adalah pelaksanaan tugas (Supardi,2014:45). Jika dilihat dari ketiga arti kata performance tersebut, kinerja bagi seorang pendidik lebih cocok diartikan sebagai pelaksanaan tugas.

Kinerja adalah kegiatan yang dilakukan seseorang dalam melaksanakan dan menyelesaikan tugas serta tanggung jawabnya berdasarkan fungsinya masing-masing 
sesuai dengan harapan dan tujuan yang telah ditetapkan dan disepakati untuk dicapai bersama-sama (Supardi,2014:45). Menurut Bambang Kusriyanto (2005:9), kinerja merupakan perbandingan antara peran yang didapat dengan hasil yang dicapai oleh seseorang.

Mulyasa (2005:136) mengutip perkataan Smith yang menyatakan bahwa kinerja adalah output drive from processes, human or otherwise. Maksudnya adalah prestasi atau kinerja merupakan hasil atau pencapaian dari suatu proses yang telah dijalani. Selanjutnya Mulyasa mengatakan bahwa kinerja atau performance dapat diartikan sebagai prestasi kerja, pelaksanaan kerja, pencapaian kerja dan hasil kerja.

Menurut Teori Gibson dalam Supardi (2014:19) bahwa kinerja guru dipengaruhi oleh tiga kelompok variabel yaitu variabel individu, variabel organisasi dan variabel psikologi. Menurut Donni Juni Priansa (2014:74) bahwa kinerja merupakan hasil kerja yang dicapai guru di sekolah dalam rangka mencapai tujuan sekolah.

Kinerja merupakan suatu konsep yang bersifat menyeluruh yang merupakan efektifitas operasional suatu organisasi, bagian organisasi dan karyawannya berdasarkan standar dan kriteria yang telah ditetapkan sebelumnya. Pada dasarnya, organisasi dijalankan oleh sekelompok manusia yang menyepakati tujuan bersama, maka kinerja sesungguhnya merupakan perilaku manusia tersebut dalam menjalankan tugas fungsi dan perannya dalam suatu organisasi yang ia ikuti, untuk memenuhi standar perilaku yang telah ditetapkan agar menghasilkan tindakan serta tujuan yang diinginkan.

Kinerja guru secara profesional mempunyai spesifikasi tertentu. Kinerja guru dapat dilihat dan diukur berdasarkan spesifikasi atau kriteria kompetensi yang harus dimiliki oleh setiap guru. Berkaitan dengan kinerja guru sebagai pendidik, wujud perilaku yang dimaksud adalah kegiatan guru dalam proses pembelajaran di kelas ataupun di luar kelas. Berkenaan dengan standar kinerja guru, Kusmianto (1997:49) dalam buku panduan penilaian kinerja guru menjelaskan bahwa standar kinerja guru itu berhubungan dengan kualitasnya dalam menjalankan tugas, seperti bekerja sama dengan siswa secara individual, mempersiapkan perangkat pembelajaran dengan menyusun Rencana Pelaksanaan Pembelajaran (RPP), pendayagunaan media pembelajaran dalam proses pembelajaran, melibatkan siswa dalam berbagai pengalaman belajar, dan memiliki jiwa kepemimpinan. Kinerja guru juga dapat dinilai pada saat seorang guru melaksanakan kegiatan belajar mengajar di kelas termasuk persiapan yang dilakukan sebelum memasuki kelas, baik dalam bentuk administrasi mengajar atau model dan media pembelajaran yang akan digunakan.

Supardi (2014:50) mengutip faktor-faktor yang mempengaruhi kinerja menurut Tempe adalah lingkungan, desain jabatan, perilaku manajemen, penilaian kinerja, umpan balik dan administrasi pengupahan atau honorarium. Sedangkan menurut Kopelman kinerja ditentukan oleh empat faktor, yaitu lingkungan kerja, karakteristik individu, karakteristik organisasi dan karakteristik pekerjaan yang dilakukan.

Srinaila (2015:7-8) membagi faktor yang mempengaruhi kinerja kedalam dua 2 faktor, yaitu internal dan faktor eksternal. Faktor internal terdiri dari kecerdasan, kecakapan dan keterampilan, minat dan bakat, kemampuan life skill, motif, kesehatan, kepribadian dan cita-cita atau tujuan yang ingin dicapai dalam pekerjaannya. 
Sedangkan faktor eksternal yang mempengaruhi kinerja terdiri dari lingkungan keluarga, lingkungan kerja, komunikasi dengan kepala sekolah, sarana prasarana dan kebijakan pemerintah.

\section{Konsep Lingkungan Pendidikan Islam}

Lingkungan meliputi semua bentuk keadaan yang dapat mempengaruhi tingkah laku, pertumbuhan dan perkembangan seseorang di dunia ini. Menurut Mohammad Surya (2014:34) lingkungan adalah segala hal yang merangsang individu, sehingga individu turut terlibat dan mempengaruhi perkembangannya. Respon terhadap lingkungan itu sendiri berbeda-beda, dalam pandangan Syaodih (2011:57) secara garis besar terdapat dua kecenderungan interaksi antara individu dengan lingkungannya, yaitu individu itu menerima lingkungannya atau individu tersebut menolak lingkungannya.

Sesuatu yang datang dari lingkungan mungkin diterima oleh individu sebagai sesuatu yang menyenangkan atau juga ditolak sebagai sesuatu yang tidak menyenangkan, tidak menguntungkan dan justru merugikan. Individu cenderung akan menerima sesuatu yang menyenangkan atau menguntungkan dan tidak merugikan dirinya. Sebaliknya, untuk hal-hal yang tidak menyenangkan atau tidak memberikan kenyamanan maka cenderung akan dihindari dan menerima penolakan (Dahlan \& Lela, 2018:297). Hal ini tidak terbatas pada lingkungan tempat berlangsungnya aktifitas kehidupan saja, namun juga dalam proses pendidikan di lingkungan pendidikan. Faktor kenyamanan akan menentukan besarnya penerimaan dari individu yang berada di lingkungan itu.

Pendidikan dilihat dari asal katanya memiliki tiga makna yaitu; Pertama. Rabaa yarbuu yan memiliki arti bertambah dan bertumbuh. Kedua. Rabiya yarba artinya menjadi besar. Ketiga. Rabba yarubbu yang bermakna memperbaki, memelihara, membentuk dan mendidik (Ma'luf, 1987:234).

Dalam terminologi Ahmad Tafsir (2008:28) memaknai pendidikan sebagai usaha yang dilakukan oleh seseorang, dalam hal ini adalah pendidik, terhadap seseorang yang disebut anak didik atau peserta didik demi terlaksananya perkembangan yang positif secara optimal. Usaha itu banyak macamnya yang bisa dilakukan, diantaranya dengan cara mengajarkan berbagai ilmu dan mengembangkan potensi, pengetahuan dan keterampilannya serta memberikan contoh (teladan) agar dapat ditiru, membiasakan perilaku baik, memberikan pujian dan hadiah kepada yang berprestasi atau memotivasi bagi yang belum berprestasi.

Kata lingkungan dan pendidikan jika disatukan maka akan memiliki makna sebagai tempat berlangsungnya kegiatan pengembangan diri seseorang. Lingkungan dalam proses pendidikan adalah tempat di mana diberlangsungkannya proses pendidikan. Dalam pandangan Syafi'i (2015:153) lingkungan pendidikan merupakan institusi atau lembaga yang di dalamnya berlangsung proses pendidikan, dan akan ada hubungan timbal balik antara lingkunga dan pendidikan yang berlangsung. Keduanya akan saling memberikan pengaruh.

Lingkungan islami adalah lingkungan yang memiliki kedamian di dalamnya, dan berlangsung kegiatan atau aktifitas-aktifas yang mencerminkan kepatuhan dan penyerahan diri kepada Allah SWT. Lingkungan pendidikan Islam secara umum 
adalah usaha yang dilakukan dalam rangka membimbing manusia untuk mewujudkan tujuan dari penciptaannya. Manusia diciptakan agar mereka mengetahui hakikat sang Pencipta, mengesakan dan memurnikan ibadah hanya kedapa Yang Maha Kuasa dan mau menghambakan diri dengan menjalankan seluruh perintahNya dan menjauhi semua laranganNya.

Secara sederhana, penulis menyimpulkan bahwa lingkungan pendidikan islam adalah tempat berlangsungnya proses pendidikan yang memiliki atmosfir dan suasala keislaman pada apa yang dilihat, didengar dan dirasakan oleh seluruh individu yang ada di dalamnya, baik yang bersifat fisik maupun non fisik.

\section{Problematika Kinerja Pendidik di Lingkungan Pendidikan Islam}

Dalam proses mencapai sebuah tujuan pendidikan, tentunya tidak akan lepas dari permasalahan-permasalahan yang ada. Baik yang bisa dipecahkan dengan mudah maupun yang sulit untuk diselesaikan. Permasalahan yang menjadi kendala pencapaian tujuan ini disebut sebagai problematika.

Seorang pendidik dalam menjalankan kewajibannya untuk mendidik, membina dan menyampaikan ilmu pengetahuan kepada peserta didik secara profesional masih akan memiliki celah-celah kekurangan. Kekurangan tersebut bertransformasi menjadi sebuah problema yang ada di dalam proses pembelajaran yang pada akhirnya akan mempengaruhi kinerja pendidik. Kinerja yang kurang baik tentunya akan berpengaruh pada kualitas pendidikan yang dihasilkan. Problematika itu bisa muncul dari dalam diri pendidik sendiri (internal) atau dari luar diri pendidik (eksternal).

Untuk ruang lingkup Kementerian Agama yang merupakan lingkungan pendidikan islam terdapat problem yang tidak sedikit. Mulai dari rendahnya kualitas guru, gaji guru honorer dan kurangnya jumlah guru di daerah. Dalam penelitianya, Wardi (2013:57) mengemukakan bahwa salah satu problem dalam dunia pendidikan islam adalah Operational problem (masalah operasional). Hal ini tentu berpengaruh terhadap penurunan kinerja guru di lingkungan pendidikan islam. Karena Pendidik dan tenaga kependidikan mulai terpecah fokusnya. Guru sekarang tidak hanya memikirkan tugasnya untuk mentransfer ilmu kepada peserta didik, namun ia juga disibukkan dengan hal-hal teknis seperti administrasi, pemberkasan tunjangan honor, tunjangan fungsional dan tunjangan sertifikasi. Maka seringkali ditemukan kasus guru meninggalkan kelas ketika pembelajaran sedang berlangsung dengan alasan mengurus pemberkasan administrasi tunjangan.

Masih berhubungan dengan operasional, dalam waktu-waktu tertentu seperti saat akan dilaksanakannya akreditasi lembaga pendidikan, guru disibukan dengan persiapan adnimistrasi yang menyita waktu, tenaga dan fikiran. Dampaknya proses pembelajaran menjadi tidak optimal.

Kejadian tersebut tidak bisa dipungkiri terjadi di beberapa lembaga termasuk di lembaga pendidikan islam karena selain memiliki fungsi moral untuk mendidik dan membina peserta didik, guru profesional juga memiliki fungsi lain yaitu fungsi kedinasan (Srinaila, 2015:202). Pada kondisi ini, keterampilan guru dalam membagi waktu sangat diperlukan. Karena ia harus melaksanakan kedua fungsinya dengan baik. Seperti yang telah dikemukakan oleh Mahmudi (2014:21), bahwa salah satu 
faktor yang mempengaruhi kinerja adalah personal guru yang meliputi: pengetahuan, keterampilan, kemampuan, kepercayaan diri, motivasi dan komitmen.

Secara profesional untuk menjalankan fungsi kedinasannya, seorang guru harus mampu memenuhi kewajibannya yang bersifat administratif. Di lembaga pendidikan islam masih banyak ditemukan guru tidak membuat Rencana Pelaksanaan Pembelajran (RPP) dalam mengajar. Mereka membuatnya hanya jika akan dilakukan monitoring oleh pengawas sekolah atau ketika akan dilaksanakan akreditasi lembaga (Rohman, 2016:68).

Permasalahan lain yang yang dihadapi oleh pendidik di lingkungan pendidikan islam adalah rendahnya penguasaan terhadap metode, model dan strategi pembelajaran. Guru belum menggunakan metode, model dan strategi yang menarik dan menyenangkan dalam proses pembelajaran khusunya yang mengajar materi keagamaan (Elfita dkk, 2019:39). Hal ini disebabkan karena guru yang mengajar materi agama terlanjur nyaman dengan metode dan model pembelajaran yang itu-itu saja. Jika tidak ceramah pasti tanya jawab.

Yahya (2015:108) mengutip pendapat Mujammil Qomar bahwa kelemahan pendidikan pesantren yang lain adalah suasana pembelajaran yang pasif. Hal ini masih banyak dijumpai di pesantren yang salah satu penyebabnya adalah minimnya kreativitas dan juga inovasi guru pesantren terhadap pengembangan metodologi pembelajaran aktif, sehingga membuat daya kritis santri menjadi lemah. Maka agar nalar kritis tumbuh di pesantren, para pendidiknya harus mau melakukan formulasi pola pendidikan dengan menyertakan metodologi modern.

Selain itu, rekrutmen ustaz dan ustazah, pengembangan akademik, reward system (sistem upah), dan bobot kerja juga tidak berdasarkan aturan yang baku. Penyelenggaraan pendidikan di pesantren seringkali dilakukan tanpa perencanaan sehingga menjadi penyebab munculnya problem kinerja pendidik di lingkungan pendidikan islam (Chudzaifah, 2018:427).

Hal diatas dapat dikategorikan dalam faktor kompetensi dan profesionalitas guru. Dalam perspektif pendidikan Agama Islam, guru seringkali mengalami hambatan dalam menanamkan pembiasaan-pembiasaan ajaran Islam di sekolah. Kesulitan tersebut disebabkan karena guru belum menguasai materi ajar sebagai salah satu kompetensinya, serta tidak didukung oleh penguasaan konsep internalisasi keilmuan antara ilmu agama dan ilmu umum oleh guru-guru bidang studi yang merupakan dampak dari dikotomi ilmu pengetahuan.

Dalam penelitiannya, Miftahur Rohman (2016:62) menyebutkan ada salah satu problematika yang berkaitan dengan kinerja guru di lingkungan pendidikan islam yaitu rendahnya minat guru untuk meneliti dan mengkaji kembali materi. Selain itu, kurangnya kemampuan guru dalam mengikuti perkembangan jaman terutama penguasaan terhadap teknologi. Maka kemudian ditemukan guru yang mengajar tidak sesuai dengan background keilmuan yang dimilikinya dan pembelajaran tidak berjalan secara menyenangkan dan interaktif.

Kejadian tersebut sering ditemukan di lembaga pendidikan islam non-pesantren. Di pesantren, guru memiliki kompetensi akademik dan menguasai materi yang diajarkan. Seorang kiai tidak akan menempatkan seorang ustadz/ustadzah untuk 
mengajarkan materi yang belum dikuasainya, karena pesantren memiliki prinsip dzollun mudzillun yang artinya 'sesat menyesatkan'. Guru yang tidak menguasai materi dikhawatirkan akan keliru dalam menyampaikan ilmunya kepada para santri. Guna memutus kemungkinan tersebut, maka di pesantren guru harus menguasai betul materi yang akan diajarkan agar tidak terjadi kesalahan. Karena salah menyampaikan materi ajar adalah sebuah 'dosa besar'.

Selain itu juga terjadi ketimpangan kesejahteraan yang sangat signifikan antara guru yang mengajar di lembaga pendidikan formal dengan pesantren yang dapat membuat kecemburuan sosial (Rohman, 2016:62). Penyebabnya adalah karena guru di pesantren, khususnya pesantren salaf, mayoritas tidak memiliki kualifikasi sebagai seorang guru profesional. Dampaknya adalah tidak diakuinya sebagai tenaga pendidik yang profesional dan tidak bisa mendapatkan tunjangan guru dari pemerintah sebagaimana yang didapatkan oleh para pendidik yang memiliki kualifikasi pendidikan dan terdaftar sebagai guru profesional.

Selanjutnya, Tanjung (2017:313) dalam penelitiannya menyebutkan problem yang dihadapi oleh pendidik di lingkungan pendidikan islam adalah rendahnya kualifikasi dan kompetensi dari kepala sekolah selaku pimpinan di lembaga tersebut. Banyak kepala madrasah yang tidak memenuhi kualifikasi dan kompetensi sebagai kepala tapi menduduki posisi central di lembaga. Pernyataan tersebut didukung oleh banyak penelitian lain diantaranya oleh Firmawati (2017:167) dan Satriadi (2016:126) yang menyatakan bahwa semakin kondusif kepemimpinan kepala sekolah maka akan semakin baik tingkat kinerja gurunya.

Pada sebuah organisasi, kesuksesan atau kegagalan pencapaian sebuah tujuan dipengaruhi oleh karakteristik gaya kepemimpinannya, melalui jiwa kepemimpinan yang kuat dan didukung oleh kapasitas organisasi yang memadai, maka penyelenggaraan proses pendidikan yang baik dapat terwujud. Karena para pendidik akan terdorong untuk terus berada dalam performa terbaiknya selama menjalankan tugas dan fungsinya sebagai pendidik profesional.

\section{Kesimpulan}

Agar Ilmu Pendidikan Islam tidak kehilangan daya tarik, kaitannya dengan kelembagaan dan fungsionalnya, diperlukan adanya perubahan paradigma, bangunan dan kerangka berfikir yang memadai dalam penyelenggaraan pendidikan Islam. Problematika di dalam dunia pendidikan islam yang setiap tahunnya muncul diharapkan menjadi bahan evaluasi agar diperbaiki dan menjadi motivasi dalam meningkatkan kualitas pendidikan di lingkungan pendidikan Islam. Pendidik memainkan peran yang berdampak pada kualitas pendidikan yang dijalankan. Secara historis, pendidik atau guru di Indonesia tidak lepas dari sistem pendidikan yang diterapkan dari masa ke masa sejak era pra kemerdekaan hingga sekarang. Munculnya masalah-masalah yang dihadapi oleh para pendidik khusunya di lingkungan pendidikan islam menjadi tolak ukur bahwa masih ada hal yang harus diperbaiki dan ditingkatkan dalam sistem pendidikan islam. Pentingnya keseriusan dalam menyeselesaikan permasalahan ini harusnya menjadi prioritas utama agar proses pendidikan bisa berjalan sesuai dengan yang diharapkan semua pihak. 
Setelah melakukan kajian koseptual pada berbagai literatur yang berkaitan dengan objek penelitian, penulis menyimpukan ada beberapa faktor yang menjadi problematika kinerja pendidik di lingkungan pendidikan islam, diantaranya: Pertama, masalah operasional. Banyaknya tuntutan yang bersifat administratif berpengaruh terhadap penurunan kinerja guru di lingkungan pendidikan islam. Karena Pendidik dan tenaga kependidikan mulai terpecah fokusnya. Guru sekarang tidak hanya memikirkan tugasnya untuk mendidik, namun ia juga disibukkan dengan hal-hal teknis seperti administrasi, pemberkasan tunjangan honor, tunjangan fungsional dan tunjangan sertifikasi. Menteri Pendidikan dan Kebudayaan (MenDikBud) Republik Indonesia, Nadiem Anwar Makarim menyatakan dalam pidatonya saat upacara peringatan Hari Guru Nasional Tahun 2019, bahwa guru terlalu banyak dibebankan aturan dan tugas administratif yang pada akhirnya berpengaruh pada kinerjanya dalam menjalankan tugasnya sebagai pendidik. Beliau mengajak seluruh guru agar senantiasa berinovasi dalam menjalankan tugasnya agar terbebas dari aturan-aturan yang membelenggu. Tapi bagi pendidik profesional yang memiliki kompetensi kepribadian yang displin dan cerdas, ia masih bisa menjalankan fungsi moral dan kedinasannya secara seimbang. Kedua, masalah kualifikasi dan kompetensi. Masih ditemukannya guru-guru yang mengajar dan tidak memiliki kualifikasi pendidikan. Seperti di pesantren yang materi ajarnya adalah mengkaji kitab kuning karya para ulama salaf. Walaupun secara kompetensi mereka menguasai materi, namun guru di pesantren yang mayoritas merupakan alumni atau santri senior di pesantren tersebut tidak memiliki kualifikasi seorang pendidik yang profesional. Hal ini tentunya berpengaruh pada penerimaan tunjangan dari pemerintah. Sebaliknya, di lembagalembaga non pesantren, guru yang memiliki kualifikasi pendidikan dari lembagalembaga pendidikan islam formal belum tentu menguasai seluruh materi yang akan diajarkan kepada peserta didik. Salah satu penyebabnya adalah pola pendidikan guru yang instan yang tidak sesuai dengan prosedur dan perundang-undangan. Banyak LPTK yang meluluskan mahasiswanya tanpa melalui tri dharma perguruan tinggi (pendidikan, penelitian, dan pengabdian kepada masyarakat) yang benar dan sesuai kurikulum pendidikan tinggi. Hal ini berbahaya karena khawatir akan menyebabkan kesalahan dalam penyampaian materi keagamaan yang dampaknya adalah kesalahan pemahaman. Ketiga, masalah kesejahteraan. Terjadi ketimpangan kesejahteraan yang sangat signifikan antara guru dilingkungan pendidikan umum dengan guru di lingkungan pendidikan islam. Hal tersebut selain berkaitan dengan kualifikasi yang telah dipaparkan di atas, juga karena niat yang luntur akibat minimnya kesejahteraan yang diterima oleh guru, terutama guru tidak tetap atau guru honor. Dengan pendapatan minim, mereka kurang antusias dalam mengajar, sehingga kurang menikmati profesinya yang membuat mereka jadi tidak profesional. Kejayaan negara islam di jaman klasik (abad 7-13 M) disebabkan karena pemerintahnya sangat memperhatikan mutu atau kualitas dan kesejahteraan para guru. Keempat, masalah kepemimpinan. Dalam berbagai literatur banyak ditemukan bahwa di lembaga pendidikan islam seorang kepala sekolah/madrasah masih memiliki gaya kepemimpinan yang konvensional sehingga berdampak pada buruknya inerja pendidik yang dibawahinya. Kualitas dan gaya kepemimpinan seorang kepala sekolah atau madrasah sangat menentukan kinerja guru. Karena kebijakan dan aturan-aturan yang dikeluarkan di lembaga tersebut menjadi dasar pelaksanaan tugas dan fungsi seorang guru. Pemimpin dan kreatif, inovatif dan visioner akan menyusun program 
yang visioner juga. Sehingga mau tidak mau guru akan meningkatkan kinerjanya sesuai yang diharapkan oleh kepala sekolah/madrasah.

\section{DAFTAR PUSTAKA}

Ad-dimasyqi, Al-Imam Abul Fida Isma'il Ibnu Kasir (2005). Tafsir Ibnu Kasir juz 4. Bandung: Sinar Baru Algensindo

Chudzaifah, Ibnu (2018). Tantangan Pondok Pesantren dalam Menghadapi Era Bonus Demografi. Al-Riwayah: Jurnal Kependidikan Volume 10, Nomor 2, Hal. 409434

E. Mulyasa (2005). Menjadi Guru Profesional. Bandung: PT. Remaja Rosda Karya

Elfita Rifa, Zulhaini \& Ikrima Mailani (2019) Pengaruh Lingkungan Kerja Terhadap Kinerja Guru Pendidikan Agama Islam Di Mts Negeri Sentajo Filial Singingi Kecamatan Singingi Kabupaten Kuantan Singingi. Jurnal Al-Hikmah Vol. 01 No. 01 Hal.37-55

Firmawati, Yusrizal \& Nasir Usman (2017) Pengaruh Kepemimpinan Kepala Sekolah Dan Motivasi Kerja Terhadap Kinerja Guru. Jurnal Magister Administrasi Pendidikan ISSN 2302-0156 Pascasarjana Universitas Syiah Kuala. Volume 5, No. 3, Hal.167-171

Hasibuan, Zainal A. (2007). Metodologi Penelitian Pada Bidang Ilmu Komputer Dan Teknologi Informasi:Konsep, Teknik, Dan Aplikasi. Jakarta: Fakultas Ilmu Komputer Universitas Indonesia.

Kosim, Muhamad (2018). Pengaruh Kepemimpinan Kepala Sekolah terhadap Kinerja Guru untuk Mewujudkan Mutu Pembelajaran. Jurnal Khazanah Akademia Vol. 01, No. 01, Hal. 30-38

Kusriyanto, Bambang (2005). Meningkatkan Produktivitas Karyawan. Jakarta : PT. Gramedia Pustaka Utama.

M. Dahlan R \& Lela Qodriah (2018). Lingkungan Pendidikan Islami Dan Hubungannya Dengan Minat Belajar Pai Siswa SMA Negeri 10 Bogor. Edukasi Islami: Jurnal Pendidikan Islam, VOL. 07 No. 02 Hal, 195 - 210

Ma'luf, Louis (1987). Al Munjid fî allughah wal a'lâm. Beirut: Dar al Masriq

Mahmudi (2014), Manajemen Kinerja Sektor Publik. Yogyakarta: UPP AMP YKPN

Priansa, Donni Juni (2014) Kinerja dan Profesionalisme Guru . Bandung: Alfabeta

Rama, Bahaking (2007), Beberapa Pandangan Tentang Guru Sebagai Pendidik. Lentera Pendidikan Vol.10, No.1 Hal.15-33

Ramayulis (2002). Ilmu Pendidikan Islam. Jakarta: Kalam Mulia 
Rohman, Miftahur (2016), Problematika Guru dan Dosen dalam Sistem Pendidikan di Indonesia, Jurnal Cendekia, Vol. 14, No. 1 Hal. 49-71.

Sahin, Abdullah (2018). Critical Issues in Islamic Education Studies: Rethinking Islamic and Western Liberal Secular Values of Education. Religion Jurnal Of University of Warwick, 9, 335; doi:10.3390/rel9110335

Satriadi (2016). Pengaruh Kepemimpinan Kepala Sekolah Terhadap Kinerja Guru. Jurnal Benefita Vol 1, No 3 Hal. 123-133

Srinaila (2015). Faktor-Faktor Penyebab Rendahnya Kinerja Guru Dan Korelasinya Terhadap Pembinaan Siswa: Studi Kasus Di Sman 1 Darul Imarah Aceh Besar. Jurnal Ilmiah DIDAKTIKA VOL. 15, No. 2, 193 - 207

Supardi, (2014). Kinerja Guru, Jakarta: Grafindo

Surya, Mohammad (2014). Psikologi Guru: Konsep Dan Aplikasinya. Bandung: Alfabeta

Syafi'i, A AS (2015). Perubahan Lingkungan Pendidikan dan cara mengantisipasinya (Suatu Kajian Filosofis dalam Pendidikan Islam), Dirasat:Jurnal Menejemen dan Pendidikan Islam. Vol. 01 No.01, hlm. 153

Syaodih, Nana Sukmadinata (2011). Landasan Psikologi Proses Pendidikan. Bandung : PT Remaja Rosakarya Offset

Tafsir, Ahmad (2008). Ilmu Pendidikan Dalam Persfektif Islam. Bandung : Rosda Karya.

Tanjung, Muhammad Arifin (2017). Headmaster Policy Of Senior Islamic School To Increas Teacher Profesionalism At State Senior Islamic School 2 Model Medan. IJLRES - International Journal on Language, Research and Education Studies Vol. 1, No. 1, Hal. 130 - 147

Umar, Bukhari (2010). Ilmu Pendidikan Islam. Jakarta: Amzah

Wardi, Moh (2013). Problematika Pendidikan Islam Dan Solusi Alternatifnya (Perspektif Ontologis, Epistemologis Dan Aksiologis). Jurnal Tadris Vol.8 No.01 Hal. 54-70

Yahya, Fata Asyrofi (2015) Problem Manajemen Pesantren, Sekolah, Madrasah: Problem Mutu Dan Kualitas Input-Proses-Output. Jurnal El-Tarbawi Vol.08 No.01 Hal.93-116 